Stawomir Rębisz

Uniwersytet Rzeszowski e-mail: rebiszuniv@poczta.onet.pl

\title{
AKTYWNOŚĆ PUBLIKACYJNA PRACOWNIKÓW SEKTORA NAUKI I BADAŃ Z POLSKI, SŁOWACJI I WĘGIER W LATACH 2005-2009 | 2010-2014
}

\section{Abstract \\ The publishing activity of Polish, Slovakian and Hungarian academics and researchers in 2005-2009 and 2010-2014}

This article is intended (1) to provide an analysis spanning over two periods 2005-2009 and 2010-2014 of the publishing activity of academics and researchers from Poland, Slovakia and Hungary, based on the data available from the Clarivate Analytics database, previously Thomas Reuters Web of Science ${ }^{\mathrm{TM}}$ Core Collection, (2) capturing certain trends within these periods (increase/decrease), concerning the participation of academics and researchers from the three countries in global science, and (3) presenting the level of their presence on the global stage. Results of the study introduces the theses that the scientific policy originated Poland and Slovakia in the period under review is bringing slow results. An increase in participants has taken place in the mentioned countries from 2010-2014 in the world of science and the presence of representatives from these countries have become more and more significant in the world scientific landscape. In addition to this their local scientific activity changes into a more open and international form. The Hungary situation in this area is not as clear. On the one hand the citation of work with Hungarian affiliation has increased, and on the other hand the scientific productivity of the representatives of the country has decreased.

Keywords: scientific productivity, Poland, Slovakia, Hungary, Web of Science 


\section{Streszczenie}

Celem niniejszego artykułu było: (1) porównanie aktywności publikacyjnej pracowników sektora nauki i badań z Polski, Słowacji i Węgier na podstawie danych zawartych w bazie Clarivate Analytics, dawniej Thomson Reuters - Web of Science ${ }^{\mathrm{TM}}$ Core Collection, w dwóch przedziałach czasowych, w latach 2005-2009 i 2010-2014; (2) uchwycenie w ciągu analizowanych lat tendencji (wzrostowych/spadkowych) w zakresie udziału przedstawicieli poszczególnych państw w światowej nauce, a tym samym (3) zaprezentowanie poziomu ich obecności w globalnym obiegu nauki. Wyniki badań pozwalają przyjąć tezę, że polityka naukowa prowadzona w Polsce i na Słowacji w omawianym okresie powoli przynosi oczekiwane rezultaty. W latach 2010-2014 udział badanych państw w światowej nauce zwiększył się, a przedstawiciele tych krajów w coraz większym stopniu są obecni w jej ponadnarodowym obiegu. Ponadto działalność naukowa tych państw z lokalnej zmienia się w bardziej otwartą i międzynarodową. W przypadku Węgier sytuacja nie jest już tak jednoznaczna. Z jednej strony cytowalność prac $\mathrm{z}$ afiliacją węgierską wzrosła, z drugiej strony zaś zmalała produktywność naukowa przedstawicieli tego kraju.

Słowa kluczowe: produktywność naukowa, Polska, Słowacja, Węgry, Web of Science

\section{Wstęp}

Dynamiczny rozwój ekonomii światowej w kierunku gospodarki opartej na wiedzy (ang. knowledge based economy) sprawił, że na niespotykaną dotąd skalę pojawiło się zapotrzebowanie na wiedzę oraz wysokie kwalifikacje. Aby sprostać temu wyzwaniu, zaczęto opracowywać i wdrażać długoterminowe plany i strategie dotyczące rozwoju badań, nauki i edukacji. W przypadku Europy w większości krajów wprowadzono już w życie lub przyjmuje się specjalne dokumenty polityczne, które nakreślają strategiczne priorytety państwa służące rozwojowi szeroko rozumianej nauki i edukacji [Higher Education Governance in Europe, 2008; Kwiek, 2015d: 211-230]. Wprawdzie konkretne rozwiązania są zróżnicowane zależnie od kraju, można jednak wyraźnie dostrzec, że priorytetem dla rządów stały się działania efektywnie wspierające międzynarodową konkurencyjność badawczą poszczególnych państw [Beblavý, 2005; Investment in the Future: National Research and Development and Innovation Strategy 2013-2020, 2013; Strategia rozwoju kraju 2007-2015. Strategia rozwoju nauki w Polsce do 2015 roku, 2008]. To właśnie w innowacyjności opartej na szeroko zakrojonych badaniach poszczególne państwa upatrują główny motor rozwoju ich gospodarek, bowiem zdolność do tworzenia innowacji staje się wyznacznikiem sukcesu w globalnej konkurencji [Wolszczak-Derlacz i in., 2010: 3].

Konkurencyjność badań naukowych w ujęciu międzynarodowym, a tym samym ocena potencjału naukowego danego kraju, regionu czy też instytucji naukowo-badawczych może być analizowana za pomocą różnorodnych wskaźników liczbowych. Głównie dokonuje się tego przez porównanie osiąganych wyników działalności badawczej. W tym celu najczęściej wykorzystywane są zestawienia aktywności publikacyjnej, częstotliwości cytowań, uzyskanych patentów i licencji 
oraz wskaźniki bibliometryczne zmierzające do zobrazowania bardziej jakościowego niż ilościowego stanu nauki [Klincewicz i in., 2012; Kwiek, 2015a; Marszakowa-Szajkiewicz, 1996; Nowak, 2006; Pianta, Archibugi, 1991; Wolszczak-Derlacz i in., 2010; Wróblewski, 2013].

Jak zauważa Aneta Drabek [2012, 2013], w kształtowaniu odpowiedniej polityki naukowej państwa coraz częściej pomocne staje się używanie metod bibliometrycznych (czy też naukometrycznych). Dzięki prowadzeniu m.in. analiz efektywności i produktywności naukowej poszczególnych jednostek, insty tucji danego państwa (uczelni, instytutów badawczych, jednostek naukowych itd.), które mają priorytetowe znaczenie w kreowaniu społeczeństwa opartego na wiedzy ${ }^{1}$, otrzymujemy aktualny obraz nauki, zarówno w ramach własnego kraju, jak w kontekście międzynarodowym. Wspomniane analizy pozwalają również przewidywać i obserwować nowe trendy badawcze, wpływać na powstanie międzynarodowych grup naukowców prowadzących badania w określonym kierunku, analizować wkład poszczególnych państw czy instytucji w rozwój nauki i badań. Jak zauważają Krzysztof Klincewicz, Marcin Żemigała i Michał Mijal [2012], podejmowanie takich systematycznych analiz bibliometrycznych może „ułatwić strategiczne zarządzanie sektorem nauki oraz budowę strategii $\mathrm{B}+\mathrm{R}$ instytucji naukowych i przedsiębiorstw poprzez dostarczenie szczegółowej wiedzy na temat tendencji w zakresie rozwoju badań naukowych i technologii" [Klincewicz i in., 2012: 16].

\section{Cele i metody badawcze}

Celem głównym niniejszego artykułu nie jest dokonanie na podstawie analizy bibliometrycznej porównania produktywności naukowej przedstawicieli świata nauki z Polski, Węgier i Słowacji ani wskazanie ich miejsca na tle naukowców $\mathrm{z}$ państw wysoko rozwiniętych, w ostatnich latach w literaturze przedmiotu pojawiło się bowiem na ten temat wiele prac [zob. m.in.: Csajbók i in., 2007; Kozak i in., 2015; Kwiek, 2015a, 2015c, 2016; Mali, 2011; Teodorescu, Andrei, 2011; Wolszczak-Derlacz i in., 2010; Wróblewski, 2005, 2013]. W prezentowanej pracy autorzy chcieli przede wszystkim znaleźć odpowiedź na pytanie, czy wdrażane przez poszczególne kraje w pierwszej dekadzie XXI wieku reformy służące rozwojowi nauki i badań analizowanych państw, a przez to wzmocnieniu międzynarodowej pozycji ich nauki poprzez jej intensywne umiędzynarodowienie, przyniosły oczekiwane rezultaty. Aby to sprawdzić, porównano aktywność publikacyjną pracowników sektora nauki i badań z Polski, Słowacji i Węgier w dwóch przedziałach czasowych, w latach 2005-2009 i 2010-2014.

1 Wspomnianą efektywność i produktywność naukową należy rozumieć jako liczbę opublikowanych prac w recenzowanych (peer-reviewed), uznanych czasopismach oraz zgłoszonych patentów do odpowiednich instytucji - np. European Patent Office (EPO) czy World Intellectual Property Organization (WIPO) [Nygaard, 2015]. 
Na podstawie analizy porównawczej danych zawartych w bazie Thomson Reuters - ISI Web of Science ${ }^{\mathrm{TM}}$ Core Collection (WoS) autorzy podjęli próbę określenia: (1) tendencji w zakresie produktywności naukowej i udziału przedstawicieli poszczególnych państw w światowej nauce w ciągu analizowanych lat (wzrost/ spadek), (2) skali umiędzynarodowienia ich dorobku naukowego (współautorstwo międzynarodowe) oraz (3) poziomu obecności naukowców z wyżej wymienionych państw w europejskim (UE) ${ }^{2}$ i światowym obiegu nauki (cytowalność).

W pierwszej kolejności dla autorów kluczowy stał się wybór odpowiedniego źródła, które zapewniłoby reprezentatywność przeprowadzonych badań. Uwzględniając fakt, że w nauce, w tym europejskiej, liczy się prestiż czasopisma, w którym ukazuje się publikacja, a hierarchia w nauce opiera się w dużej mierze właśnie na funkcjonującej globalnie hierarchii czasopism naukowych [Kwiek, 2015b], w niniejszym artykule, jak już wspomniano, wykorzystano dane zaczerpnięte z bazy Thomson Reuters (Web of Science ${ }^{\mathrm{TM}}$ Core Collection). Indeksuje ona prace wyselekcjonowane i uznane za istotne [Wróblewski, 2013], mające Impact Factor (IF), będący uznanym wskaźnikiem wpływu naukowego na świecie ${ }^{3}$. Liczba publikacji w czasopismach o wysokim IF staje się miarą jakości badań naukowych, a tym samym określa stopień poziomu umiędzynarodowienia nauki.

Łącznie we wspomnianej bazie indeksowanych jest prawie 12 tys. czasopism (dane na koniec roku 2015), uwzględniających 234 dyscypliny naukowe ${ }^{4}$ [Thomson Reuters, 2016b].

Dokonanie porównania produktywności naukowej w podanych przedziałach czasowych na podstawie artykułów zindeksowanych $\mathrm{w} \mathrm{WoS}^{\mathrm{cc}}$ wydaje się zasadne, zważywszy na fakt, że poszczególne kraje w omawianym okresie wdrożyły m.in. oficjalne kryteria oceny dorobku jednostek naukowych i poszczególnych pracowników przez wzmacnianie znaczenia publikacji w czasopismach o zasięgu międzynarodowym [Lewicka, 2009].

2 Ilekroć w artykule pojawia się odniesienie do Unii Europejskiej (UE), autorzy dla porównywalności wyników w analizowanym okresie (2005-2014) uwzględniają dane 28 państw wchodzących obecnie w skład Unii.

3 Baza WoS indeksuje tylko czasopisma spełniające określone wymogi: (1) czasopismo musi podawać tytuły, słowa kluczowe i abstrakty artykułów w języku angielskim; (2) wymóg kwalifikacji artykułów na podstawie ,ślepych recenzji”; (3) wymóg ciągłości wydawniczej; (4) wymóg, aby środowisko autorów było międzynarodowe [Krysztofiak-Szopa, 2006: 4]. O roli, jaką odgrywają bazy Web of Science, niech świadczy fakt, iż to na ich podstawie przygotowuje się wskaźniki impact factor (IF) [De Bellis, 2009: 187].

4 Podana $w$ artykule liczba dyscyplin naukowych nie zawsze pokrywa się z grupami nauk i kierunkami w danym kraju. Wynika $\mathrm{z}$ istniejących w pakiecie Web of Science ${ }^{\mathrm{TM}}$ Core Collection baz, które w taki właśnie sposób obejmują swym zakresem nauki przyrodnicze i technikę (baza SCI), nauki społeczne (baza SSCI) oraz nauki o sztuce i nauki humanistyczne (baza A\&HCI). Należy przy tym pamiętać, iż zakresy tematyczne przedstawionych baz danych (dyscypliny) krzyżują się. I tak np. publikacje z dziedziny informacji naukowej, cybernetyki, zarządzania mogą znaleźć się zarówno w przyrodniczej bazie danych SCI, jak i w społecznej SSCI. Z kolei czasopisma medyczne opracowywane są głównie w przyrodniczej bazie danych, chociaż pewna część czasopism medycznych włącza się tylko do bazy nauk społecznych SSCI [Marszakowa-Szajkiewicz, 1996: 18]. 
Aby wyeliminować wahania i pokazać stopień aktywności publikacyjnej przedstawicieli nauki z poszczególnych krajów, przeprowadzone analizy oparto na danych gromadzonych w ciągu kilku lat, z podziałem na dwa okresy, tzn. na lata 2005-2009 i 2010-2014. Dzięki takim zestawieniom łatwo zauważyć rosnącą lub malejąca rolę państw czy instytucji w międzynarodowej aktywności badawczej w danych dziedzinach wiedzy [Drabek, 2013].

Kolejną istotną kwestią, którą wzięto pod uwagę przy dokonywaniu porównań, było określenie typów dokumentów wliczanych do analizy i porównywanych ${ }^{5}$. Jeśli liczba publikacji ma miarodajnie służyć do porównywania potencjału twórczego, powinna obejmować tylko oryginalne artykuły naukowe, książki i rozdziały z książek, materiały konferencyjne i artykuły przeglądowe. Pozostałe typy są pochodną pierwotnych dokumentów i często zawyżają rzeczywistą liczbę analizowanych prac [zob.: Przyłuska, Maczuga, 2011].

Autorzy niniejszej pracy uwzględnili w badaniach artykuły (article), rozdziały z książek (book chapter) i książki (books), materiały konferencyjne (proceedings paper) i artykuły przeglądowe (review), indeksowane w omawianej bazie w latach 2005-20146. Wskaźniki budowano z wykorzystaniem metody whole counting. Oznacza to, że każdej instytucji, w której pracowali współautorzy analizowanego tekstu, przyporządkowano jedną publikację. Kryterium wyszukiwania prac

5 Baza Web of Science (WoS) zawiera m.in. oryginalne artykuły naukowe, ich streszczenia, prace przeglądowe, książki, rozdziały w książkach, recenzje, materiały redakcyjne, listy do redakcji, uwagi, streszczenia ze zjazdów, materiały konferencyjne itd.

6 Ilekroć w niniejszym artykule autorzy wspominają o publikacjach/pracach indeksowanych w bazie WoS, odnoszą się tylko do wymienionych typów prac indeksowanych w tej bazie. W rzetelnej analizie bibliometrycznej niezwykle ważna jest nie tylko kontekstualizacja dziedzinowa czy czasowa, lecz także normalizacja ze względu na rodzaj dokumentu. Różne charakterystyki cytowalności (citation behaviours) wykluczają porównywanie ze sobą publikacji o zupełnie odmiennych typach, np. tradycyjnych artykułów naukowych publikowanych w wydawnictwach ciągłych z okazjonalnie ukazującymi się listami redakcyjnymi, życiorysami autorów czy wybitnych postaci. W analizie cytowalności i wpływu publikacji powszechnie i od dawna uwzględnianym rodzajem dokumentów jest artykuł naukowy (article). Dodatkowy typ dokumentów, stosowany choćby w kalkulacji wskaźnika Journal Impact Factor, to także obszerniejsze artykuły przeglądowe (reviews). Bardzo ważnym nośnikiem treści i odkryć na temat badań, w wielu przypadkach trzecim, a nawet drugim co do popularności, stały się materiały konferencyjne (confererence proceedings/ proceedings paper). Referaty konferencyjne prezentowane podczas licznych sympozjów i wydarzeń publikowane są $\mathrm{w}$ formie pisemnej jako elementy wydawnictw pokonferencyjnych czy wydań numerów czasopism. Nie sposób też pominąć istotności publikacji książkowych, które z kolei odgrywają ważną rolę szczególnie w naukach humanistycznych. Ponieważ sama książka naukowa to często zbiór wielu odrębnych rozdziałów autorstwa różnych osób, nabiera też znaczenia typ publikacji rozdział książkowy (book chapter), który w wielu przypadkach ma charakter artykułu naukowego zamieszczonego w zbiorczym wydaniu danej książki. $Z$ tych właśnie względów autorzy niniejszego artykułu zdecydowali się w swych analizach uwzględnić wymienione typy dokumentów jako najbardziej powszechne, dominujące w mierzeniu wpływu publikacji określanego przez cytowalność, a jednocześnie podobne w swej formie i mające podobny poziom charakterystyki cytowań w swych dziedzinach. Autorzy zrezygnowali jednocześnie z innych form prac, nieposiadających tych cech i mających dużo mniejsze, wręcz marginalne znaczenie dla analizy bibliometrycznej. 
dotyczyło publikacji, których przynajmniej jeden autor podawał afiliację analizowanego kraju - Polski, Węgier i Słowacji.

Wspomniane dwa podokresy (2005-2009 i 2010-2014) zostały wybrane z kilku powodów. Lata 2005-2009 to czas, gdy omawiane państwa zaczynają funkcjonować w nowej rzeczywistości wynikającej z ich przystąpienia w 2004 roku do Unii Europejskiej, stają się w pełni uczestnikami procesu tworzenia Europejskiego Obszaru Badawczego. Ponadto pierwsze lata XXI wieku to okres powszechnego wdrażania lub przyjmowania przez te państwa specjalnych dokumentów politycznych, które nakreślały na kolejne lata strategiczne priorytety państwa, obejmujące wdrażanie reform szkolnictwa wyższego oraz rozwój szeroko rozumianej nauki i badań, w tym wzmocnienie międzynarodowej pozycji nauki tych państw przez jej intensywne umiędzynarodowienie [Beblavý, 2005; Górniak, 2015; Higher Education Governance in Europe, 2008: 119; Kwiek, 2015a]. Jak pisze Marek Kwiek [2015c], internacjonalizacja badań, będąca w analizowanych państwach jednym z głównych celów ostatnich reform, ma uwzględniać dwa filary [Knight, 2012]: zwiększanie liczby publikacji danego kraju w globalnym obiegu naukowym (jako część procesu „umiędzynarodowienia u siebie”) i wzmacnianie międzynarodowej współpracy naukowej (jako część procesu „umiędzynarodowienia za granicą" [Kwiek, 2015c: 40]. Drugi uwzględniony w analizie przedział czasowy (2010-2014) to generalnie okres realizacji przyjętych wcześniej strategii rozwoju wspomnianego sektora.

\section{Analiza wyników}

\section{I. Liczba publikacji w światowych zasobach bazy Web of ScienceTM Core Collection: Polska, Węgry i Słowacja}

Liczba prac z polską afiliacją zindeksowanych w bazie WoS ${ }^{\mathrm{CC}}$ (przynajmniej jeden autor publikacji podawał afiliację z Polski), w latach 2005-2009 wynosiła 98,64 tys., co stanowiło w tym czasie ok. 1,41\% udziału w światowych zasobach wszystkich indeksowanych w tej bazie prac, i 4,11\% w ogólnej liczbie prac 28 obecnych członków UE7. W przypadku analizowanych tekstów z węgierską afiliacją, liczba odnalezionych rekordów wyniosła 31,23 tys., co stanowiło analogicznie ok. 0,45\% ogółu prac w bazie. Wskaźniki te w odniesieniu do Słowacji kształtowały się na poziomie 15,8 tys. prac, $\mathrm{z}$ udziałem w światowych zasobach na poziomie $0,23 \%$. Łącznie udział tych państw w światowym dorobku

7 W latach 2005-2009 ogólna liczba wszystkich prac (artykuły, rozdziały z książek i książki, artykuły przeglądowe i materiały konferencyjne) w bazie $W_{0} S^{\mathrm{cc}}$ wynosiła ok. 6984,45 tys., w tym 2398,31 tys. stanowiły publikacje 28 obecnych członków UE, z kolei w drugim analizowanym okresie (lata 2010-2014) analogicznie w bazie WoS 8910,05 tys., z tego 2984,80 to publikacje państw członkowskich UE [za: InCites Dataset, 2016]. 
prac zindeksowanych w bazie WoS w latach 2005-2009 wyniósł 2,09\% i 6,7\% dorobku obecnych członków UE (tabela1).

Tabela 1.

Liczba i procentowy udział prac* z Polski, Węgier i Słowacji w zasobach bazy WoS w latach 2005-2009 i 2010-2014 (w tys.)

\begin{tabular}{|c|c|c|c|c|c|c|c|c|c|c|}
\hline \multirow{3}{*}{ Wskaźniki } & \multicolumn{8}{|c|}{ Kraj i wybrane lata } & \multirow{2}{*}{\multicolumn{2}{|c|}{$\begin{array}{c}\text { Liczba wszyst- } \\
\text { kich prac** } \\
\text { w bazie WoS, } \\
\text { w poszczegól- } \\
\text { nych okresach }\end{array}$}} \\
\hline & \multicolumn{2}{|c|}{ Polska } & \multicolumn{2}{|c|}{ Węgry } & \multicolumn{2}{|c|}{ Słowacja } & \multirow{2}{*}{\begin{tabular}{|l} 
UE** \\
$2005-$ \\
2009
\end{tabular}} & \multirow{2}{*}{\begin{tabular}{|l|} 
UE** \\
$2010-$ \\
2014
\end{tabular}} & & \\
\hline & $\begin{array}{l}2005 \\
2009\end{array}$ & $\begin{array}{l}2010- \\
2014\end{array}$ & $\begin{array}{l}2005 \\
2009\end{array}$ & $\begin{array}{l}2010- \\
2014\end{array}$ & $\begin{array}{l}2005 \\
2009\end{array}$ & $\begin{array}{l}2010- \\
2014\end{array}$ & & & $\begin{array}{l}2005- \\
2009\end{array}$ & $\begin{array}{l}2010- \\
2014\end{array}$ \\
\hline $\begin{array}{l}\text { Liczba prac* } \\
\text { w światowych } \\
\text { zasobach } \\
\text { WoS }^{\mathrm{CC}}\end{array}$ & 98,64 & 135,66 & 31,23 & 36,98 & 15,80 & 24,13 & 2398,31 & 2984,80 & 6984,45 & 8910,05 \\
\hline $\begin{array}{l}\text { Procentowy } \\
\text { udzial prac* } \\
\text { w światowych } \\
\text { zasobach } \\
\text { WoS } \\
\text { CC }\end{array}$ & $1,41 \%$ & $1,52 \%$ & $0,45 \%$ & $0,41 \%$ & $0,23 \%$ & $0,27 \%$ & $34,34 \%$ & $33,50 \%$ & $100 \%$ & $100 \%$ \\
\hline
\end{tabular}

* W analizie uwzględniono: artykuły, rozdziały z książek i książki, artykuły przeglądowe i materiały konferencyjne.

** W analizie uwzględniono dane z 28 państw będących obecnie członkami Unii Europejskiej. Źródło: obliczenia własne na podstawie danych z bazy Web of Science ${ }^{\mathrm{TM}}$ Core Collection [InCites Dataset, 2016].

Drugim okresem uwzględnionym w porównawczej analizie produktywności naukowej są lata 2010-2014 (tabela 1). Należy zaznaczyć, że wszystkich ogółem zindeksowanych w bazie WoS ${ }^{\mathrm{CC}}$ prac uwzględnionych $\mathrm{w}$ niniejszej analizie było wówczas ok. 8910,05 tys., z tego 2984,8 tys. pochodziło z UE [za: InCites Dataset, 2016]. Porównując ten wskaźnik z danymi z lat 2005-2009, zauważamy, że w drugim okresie średni roczny przyrost liczby rekordów odnoszących się do wyselekcjonowanych publikacji w światowych zasobach bazy WoS ${ }^{\mathrm{CC}}$ wzrósł o nieco ponad 27\%, a w przypadku UE wzrost zanotowano na poziomie ok. $25 \%$.

W przypadku Polski liczba analizowanych prac w WoS ${ }^{C C}$ w latach 20102014 wyniosła 135,66 tys., więc ogólna liczba publikacji z afiliacją polską wzrosła o 37,5\% w stosunku do wcześniejszego analizowanego okresu (98,64 tys.), a udział procentowy tych prac w światowych zasobach bazy zwiększył się o 0,11 punktu procentowego - do poziomu $1,52 \%$ oraz do $4,55 \%$ udziału w publikacjach pochodzących z UE (tabela 1). Zatem produktywność naukowa polskich autorów w latach 2010-2014 w porównaniu z produktywnością w latach 2005-2009 okazała się wyższa prawie o $10 \%$ od średniej światowej w tym zakresie $(27,5 \%)$ i o $12,5 \%$ od średniej w UE (25\%). Pozwoliło to na zwiększenie udziału polskich 
publikacji w światowych zasobach bazy o 8\% w stosunku do lat 2005-2009 i prawie o $11 \% \mathrm{w}$ grupie publikacji z UE.

Progres w omawianej kwestii nastąpił także w przypadku autorów tekstów $\mathrm{z}$ afiliacją słowacką. Okazuje się, że średnioroczna liczba wyselekcjonowanych słowackich prac w bazie $\mathrm{WoS}^{\mathrm{CC}}$ w latach 2010-2014 w porównaniu $\mathrm{z}$ danymi z lat 2005-2009 wzrosła o 53\%, do 24,13 tys. rekordów. Taki stan rzeczy nie pozostał bez wpływu na zwiększenie udziału słowackich publikacji w światowych zasobach ogółem. W okresie od 2010 do 2014 roku wyniósł on 0,27\%. We wcześniejszym okresie było to $0,23 \%$, wzrost nastąpił zatem o $17 \%$. Także udział publikacji ze słowacką afiliacją w ogólnej liczbie prac pochodzących z UE zindeksowanych w bazie WoS wzrósł prawie o $23 \%$ - z $0,66 \%$ do wartości $0,81 \%$ (tabela 1 ).

$\mathrm{Z}$ odmienną sytuacją mamy do czynienia na Węgrzech. Mimo zwiększenia się ogólnej liczby analizowanych publikacji naukowych indeksowanych w bazie WoS ${ }^{\mathrm{CC}}$ w latach 2010-2014 do wartości 36,98 tys. (wzrost w stosunku do okresu 2005-2009 o 18\%) udział tych prac w światowych zasobach ogółem spadł do wartości $0,41 \%$. W latach $2005-2009$ wynosił on bowiem $0,45 \%$, zanotowano zatem spadek o $10 \%$. Także udział tych prac w ogólnej liczbie tekstów pochodzących z UE zindeksowanych w bazie WoS obniżył się prawie o $5 \%$ z 1,30\% do wartości 1,24\% (tabela 1).

\subsection{Liczba prac z Polski, Węgier i Słowacji w bazie WoScc przypadająca na jednego pracownika sektora nauki i badań w latach 2005-2009 i 2010-2014}

Aby dopełnić obrazu produktywności naukowej przedstawicieli omawianych krajów w latach 2005-2009 i 2010-2014, warto zaprezentować dane dotyczące liczby analizowanych publikacji indeksowanych w bazie WoS, przypadających na jednego zatrudnionego w sektorze nauki i badań (uczelnie, instytuty badawczo-rozwojowe itd.).

W latach 2005-2009 liczba nauczycieli akademickich w Polsce zatrudnionych na pełny etat w uczelniach wynosiła średnio 96,181 tys. [GUS, 2006, 2007, 2008, $2009,2010]$. W pozostałych instytucjach badawczo-rozwojowych (poza szkolnictwem wyższym) osób zatrudnionych na stanowiskach badawczych, researchers, pracowało w tym okresie średnio ok. 61,21 tys. [OECD.Stat, 2016], przy czym pośród nich 38,94 tys. zatrudnionych było w szkolnictwie wyższym [OECD.Stat, 2016]. Zatem przy analizie liczby prac $\mathrm{z}$ polską afiliacją indeksowanych w bazie WoS ${ }^{C C}$ przypadających na jednego pracownika naukowego uwzględniono średnio 118,45 tys. osób. W pierwszym analizowanym okresie w bazie $\mathrm{WoS}^{\mathrm{CC}}$ znajdowało się 98,64 tys. polskich publikacji. Liczba prac przypadających na jednego polskiego pracownika sektora nauki i badań wyniosła zatem ok. 0,83 (tabela 2). 
Tabela 2

Liczba prac* na jednego pracownika sektora nauki i badań z Polski, Węgier i Słowacji w bazie WoS (lata 2005-2009 i 2010-2014)

\begin{tabular}{|c|c|c|c|c|c|c|}
\hline \multirow{3}{*}{ Wskaźniki } & \multicolumn{6}{|c|}{ Kraj i wybrane lata } \\
\hline & \multicolumn{2}{|c|}{ Polska } & \multicolumn{2}{|c|}{ Węgry } & \multicolumn{2}{|c|}{ Słowacja } \\
\hline & $\begin{array}{l}2005- \\
2009\end{array}$ & $\begin{array}{l}2010- \\
2014\end{array}$ & $\begin{array}{l}2005- \\
2009\end{array}$ & $\begin{array}{l}2010- \\
2014\end{array}$ & $\begin{array}{l}2005- \\
2009\end{array}$ & $\begin{array}{l}2010- \\
2014\end{array}$ \\
\hline $\begin{array}{l}\text { Liczba prac* } \\
\text { w światowych } \\
\text { zasobach WoS } \\
\text { (w tys.) }\end{array}$ & 98,64 & 135,66 & 31,23 & 36,98 & 15,80 & 24,13 \\
\hline $\begin{array}{l}\text { Średnia liczba } \\
\text { pracowników sek- } \\
\text { tora nauki i badań } \\
\text { (w tys.) }\end{array}$ & 118,45 & 127,35 & 34,32 & 39,07 & 14,87 & 16,11 \\
\hline $\begin{array}{l}\text { Liczba prac* na } \\
\text { jednego pracowni- } \\
\text { ka sektora nauki } \\
\text { i badań }\end{array}$ & 0,83 & 1,06 & 0,91 & 0,95 & 1,06 & 1,50 \\
\hline
\end{tabular}

* W analizie uwzględniono: artykuły, rozdziały z książek i książki, artykuły przeglądowe i materiały konferencyjne.

Źródło: obliczenia własne na podstawie danych bazy Web of Science ${ }^{\mathrm{TM}}$ Core Collation [InCites Dataset, 2016].

W przypadku Węgier w latach 2005-2009 w sektorze szkolnictwa wyższego pracowało na pełnym etacie średnio 22,41 tys. nauczycieli akademickich [Hungarian Central Statistical Office, 2016]. W sektorze Badania i Rozwoju (B + R) na pełnym etacie zatrudnionych było $\mathrm{w}$ tym okresie średnio 17,88 tys. badaczy, $\mathrm{z}$ tego 5,97 tys. to pracownicy szkół wyższych [OECD.Stat, 2016]. W analizie wspomnianego wskaźnika uwzględniono zatem 34,32 tys. pracowników sektora nauki i badań. $\mathrm{Z}$ kolei liczba węgierskich prac $\mathrm{w}$ bazie $\mathrm{WoS}^{\mathrm{CC}} \mathrm{w}$ analizowanym okresie wynosiła 31,23 tys. rekordów. Wynika z tego, że na jednego pracownika naukowego przypadało ok. 0,91 tego typu publikacji (tabela 2).

Na Słowacji w latach 2005-2009 w sektorze szkół wyższych na pełnym etacie zatrudnionych było średnio 10,41 tys. nauczycieli akademickich [Statistical Office of the Slovak Republic, 2010: 179]. W tym czasie w sektorze B + R pracowało średnio 12,18 tys. badaczy, z których 7,72 tys. to nauczyciele akademiccy [OECD. Stat, 2016]. Daje to łącznie 14,87 tys. pracowników sektora nauki i badań. Liczba słowackich tekstów indeksowanych w bazie w omawianym okresie wyniosła 15,80 tys. Uzyskany wskaźnik prac z afiliacją słowacką w bazie WoS ${ }^{\mathrm{CC}}$ przypadających na jednego pracownika nauki wyniósł zatem 1,06 (tabela 2).

Lata 2010-2014 przyniosły w omawianym zakresie pewne zmiany. Ogólnie rzecz ujmując, wskaźnik liczby publikacji w bazie $\mathrm{WoS}^{\mathrm{CC}}$ przypadających na jednego pracownika naukowego w każdym $\mathrm{z}$ krajów uwzględnionym $\mathrm{w}$ badaniu uległ wzrostowi, choć w różnym stopniu (tabela 2). Największy progres nastąpił 
w przypadku tekstów z polską afiliacją, bowiem w latach 2010-2014 liczba prac na jednego pracownika sektora nauki i badań wyniosła 1,06 publikacji, a więc wskaźnik ten wzrósł prawie o 28\% w stosunku do okresu 2005-2009 (0,83 pracy na jednego pracownika). Tak jak we wcześniejszym badanym okresie liczba tekstów z polską afiliacją przypadająca na jednego pracownika obliczona została na podstawie średniej liczby zatrudnionych nauczycieli akademickich w sektorze szkolnictwa wyższego w Polsce w latach 2010-2014 (96,97 tys.) [GUS, 2011, 2012, 2013, 2014, 2015] i średniej liczby pełnoetatowych pracowników naukowo-badawczych sektora B + R (69,16 tys.), spośród których 38,77 tys. to nauczyciele zatrudnieni w szkołach wyższych [OECD.Stat, 2016]. Łącznie w analizie uwzględniono zatem średnio 127,35 tys. pracowników sektora nauki i badań. W tym czasie w bazie $\mathrm{WoS}^{\mathrm{CC}}$ znajdowało się 135,66 tys. prac z polską afiliacją (tabela 2).

Jak wynika $z$ danych, w obu analizowanych okresach przyrost liczby prac ze słowacką afiliacją przypadających na jednego pracownika sektora nauki i badań na Słowacji w porównaniu z danymi z Polski był znacznie wyższy (prawie o $42 \%$ ). Wskaźnik ten wyniósł dla słowackich autorów 1,50 i był najwyższy wśród porównywanych państw (tabela 2). Należy tu zaznaczyć, że średnia liczba nauczycieli akademickich zatrudnionych na pełnych etatach w szkołach wyższych Słowacji w latach 2010-2014 wynosiła 10,84 tys. [Statistical Office of the Slovak Republic, 2015: 20], przy czym 9,78 tys. spośród nich pracowało w sektorze badań i rozwoju [OECD.Stat, 2016], a w całym sektorze $B+R$ na pełnym etacie średnio pracowało (łącznie z nauczycielami akademickimi) ok. 15,05 tys. badaczy [OECD.Stat, 2016]. Zatem do obliczenia wskaźnika liczby analizowanych publikacji przypadających na jednego pracownika sektora nauki i badań uwzględniono 16,11 tys. pracowników, przy ogólnej liczbie prac z afiliacją słowacką w bazie wynoszącej 24,13 tys. rekordów (tabela 2).

Najniższy wzrost w omawianej kwestii zanotowano na Węgrzech. Wskaźnik liczby publikacji z afiliacją węgierską przypadający na jednego pracownika sektora nauki i badań w latach 2010-2014 wyniósł 0,95 (w okresie 2005-2009 osiągnął wartość 0,81 ) (tabela 2). Wzrósł on zatem tylko o $17 \%$. W tym czasie na wszystkich węgierskich uczelniach zatrudnionych było średnio ok. 21,12 tys. nauczycieli akademickich [Hungarian Central Statistical Office, 2016], a w szeroko rozumianym sektorze B + R 23,89 tys. pełnoetatowych badaczy [OECD.Stat, 2016]. Z tym że wśród nich 5,95 tys. zatrudnionych stanowili pracownicy sektora szkolnictwa wyższego [OECD.Stat, 2016]. Zatem do obliczenia wskaźnika liczby analizowanych węgierskich publikacji przypadających na pracownika z sektora nauki i badań uwzględniono 39,07 tys. osób. W tym czasie w bazie $\mathrm{WoS}^{\mathrm{CC}}$ znajdowało się, jak już wspomniano, 36,98 tys. rekordów prac z węgierską afiliacją (tabela 2).

\subsection{Cytowalność}

Wskaźnikiem prezentującym obecność danego państwa w bazie Web of Science ${ }^{\mathrm{TM}}$ Core Collection jest liczba cytowań artykułów z co najmniej jedną afiliacją danego kraju. Właśnie cytowania w ostatnich latach stały się jedną z podstawowych 
miar używanych do oceny aktywności naukowej pracowników nauki, jednostek naukowo-badawczych i państw. Jest to niewątpliwie wyznacznik popularności dorobku badaczy z danego kraju, a także w pewnym sensie jakości prezentowanych badań, mimo wielu trudności interpretacyjnych związanych z tym miernikiem [Olechnicka, Płoszaj, 2009: 38]. Do uchwycenia efektywności naukowej pracowników akademickich $\mathrm{z}$ badanych państw w poszczególnych przedziałach czasowych została przeprowadzona analiza $\mathrm{w}$ ramach jednego $\mathrm{z}$ działów scientometrii (bibliometrii) [De Bellis, 2009: 1-22], tj. teorii cytowań [Leydesdorff, 1998: 5] $]^{8}$. Założono, że cytujący uznaje wartość naukową pracy cytowanej, w konsekwencji zaś, iż prace często cytowane wnoszą istotną wartość do nauki. Inaczej mówiąc, są pozycjami wpływowymi.

W niniejszej analizie do omówienia kwestii cytowalności wykorzystano wskaźnik Category Normalized Citation Impact $(\mathrm{CNCI})^{9}$. W opinii autorów właśnie ten wskaźnik pozwala w sposób prawidłowy i porównywalny uchwycić omawiane zagadnienie. Wynika to z tego, że kalkulacja wskaźnika CNCI przedstawia realny wpływ publikacji mierzony liczbą cytowań w odniesieniu do średniej liczby cytowań wszystkich innych prac w danej dziedzinie tematycznej, danym roku i danym rodzaju dokumentu. Wskaźnik CNCI pozwala zatem, w sposób uzasadniony i rzetelny, porównywać ze sobą dorobek naukowy m.in. państw i instytucji. Jest też uprawnioną miarą wskazywania efektywności publikacyjnej, a nie jedynie produktywności [Thomson Reuters, 2016a].

Biorąc pod uwagę uzyskany przez badane kraje wskaźnik CNCI (łącznie za dany okres), zauważamy, że w latach 2005-2009 prace zarówno z afiliacją polską, węgierską, jak i słowacką osiągnęły wartość niższą od 1 . Oznacza to, że w tym okresie opublikowane teksty z afiliacjami tych państw indeksowane w bazie WoS miały słabszą moc oddziaływania niż wszystkie łącznie prace w ujęciu regionalnym (UE-28) czy globalnym (tabela 3).

Sytuacja zmieniła się w latach 2010-2014. Dla badanych państw w tym okresie wskaźnik CNCI wzrósł. W przypadku publikacji z afiliacją słowacką $(1,1)$ i węgierską $(1,04)$ był on wyższy od 1 , a więc można uznać, że prace autorów z tych państw mają wyższy od oczekiwanego poziom oddziaływania, i uznać je należy za wybitne. Mimo że w latach 2010-2014 wskaźnik CNCI wzrósł także dla polskich prac, to nadal w analizowanym okresie był niższy od $1(0,92)$, a więc indeksowane w bazie polskie teksty miały słabszą moc oddziaływania niż teksty węgierskie, a w szczególności słowackie (tabela 3). Bardziej szczegółowo tendencje

8 Bibliometria to dyscyplina badawcza stosująca metody ilościowe do analiz publikacji. Do jej narodzin przyczyniło się założenie w 1963 roku przez Eugene'a Garfielda Science Citation Index, rejestru publikacji naukowych i zawartych w nich cytatów.

9 Category Normalized Citation Impact (CNCI) jest najważniejszym z grupy znormalizowanych wskaźników narzędzia InCites. W sposób realny i w kontekście przedstawia wpływ publikacji bądź grupy publikacji w swojej dziedzinie. Kalkulacja tego wskaźnika przedstawia liczbę cytowań na pracę $\mathrm{w}$ odniesieniu do grupy wszystkich innych prac w danej dziedzinie tematycznej, danym roku i danym rodzaju dokumentu. Średnia wartość wskaźnika w ujęciu globalnym wynosi zawsze 1. Dlatego też wszystkie prace posiadające wskaźnik o wartości $>1$ uznaje się za wybitne, o wyższym od oczekiwanego poziomie oddziaływania [Thomson Reuters, 2016a]. 
zmian tego wskaźnika (CNCI) w poszczególnych latach dla prac z afiliacją badanych krajów przedstawia wykres 1.

Tabela 3

Cytowalność według wskaźnika CNCI* dla publikacji z Polski, Węgier i Słowacji w latach 2005-2009 i 2010-2014

\begin{tabular}{|l|c|c|c|c|}
\hline \multirow{2}{*}{ Obszar } & \multicolumn{2}{|c|}{ Publikacje w bazie WoS (w tys.) } & \multicolumn{2}{c|}{ CNCI (lącznie za lata) } \\
\cline { 2 - 5 } & $\mathbf{2 0 0 5 - 2 0 0 9}$ & $\mathbf{2 0 1 0 - 2 0 1 4}$ & $\mathbf{2 0 0 5}-\mathbf{2 0 0 9}$ & $\mathbf{2 0 1 0 - 2 0 1 4}$ \\
\hline GlobaInie & 6984,45 & 8910,05 & 0,99 & 0,98 \\
\hline UE-28 & 2398,31 & 2984,80 & 1,09 & 1,13 \\
\hline Polska & 98,64 & 135,66 & 0,74 & 0,92 \\
\hline Węgry & 31,23 & 36,98 & 0,89 & 1,04 \\
\hline Słowacja & 15,80 & 24,13 & 0,66 & 1,1 \\
\hline
\end{tabular}

* CNCI - Category Normalized Citation Impact.

Źródło: obliczenia własne na podstawie danych z bazy Web of Science ${ }^{\mathrm{TM}}$ Core Collection [InCites Dataset, 2016].

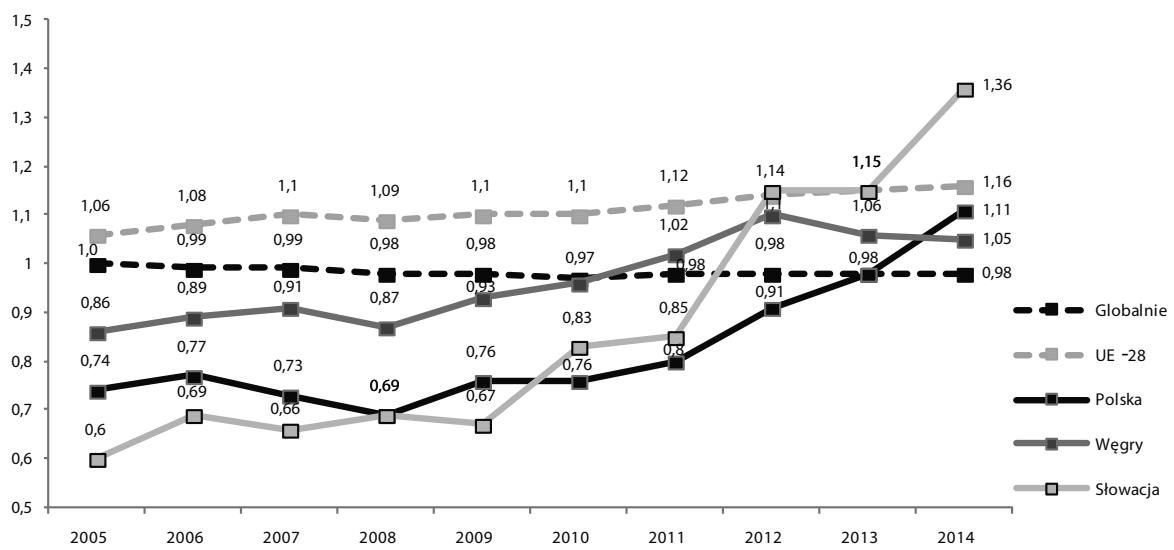

Wykres 1. Cytowalność według wskaźnika CNCI dla publikacji* z Polski, Węgier i Słowacji w latach 2005-2014

* W analizie uwzględniono: artykuły, rozdziały z książek i książki, artykuły przeglądowe i materiały konferencyjne.

Źródło: obliczenia własne na podstawie danych z bazy Web of Science ${ }^{\mathrm{TM}}$ Core Collection [InCites Dataset, 2016]. 


\subsection{Współautorstwo międzynarodowe}

Coraz częściej instytucje naukowo-badawcze są aktywnymi uczestnikami międzynarodowych projektów badawczych, a publikacje ze współautorami reprezentującymi zagraniczne ośrodki dobrze dokumentują przypadki ponadnarodowej współpracy badawczej. Interesujące może być zatem porównanie stopnia umiędzynarodowienia badań prowadzonych przez poszczególne kraje. Taki wskaźnik odzwierciedla wymierne rezultaty wspólnych prac.

Kolejna analiza dotyczyła zatem pomiaru stopnia umiędzynarodowienia publikacji z wybranych do analizy państw (ich instytucji naukowych) - zbadano, jaki udział w ogólnej liczbie artykułów mają te publikacje, które zostały stworzone wspólnie z reprezentantami instytucji naukowych z innych krajów (tabela 4).

Tabela 4

Liczba publikacji* ogółem z międzynarodowym współautorstwem indeksowanych w bazie WoS w latach 2005-2009 i 2010-2014: Polska, Węgry, Słowacja

\begin{tabular}{|c|c|c|c|c|c|c|c|c|}
\hline \multirow[t]{2}{*}{ Obszar } & \multicolumn{2}{|c|}{$\begin{array}{l}\text { Liczba publika- } \\
\text { cji w bazie WoS } \\
\text { (tys.) }\end{array}$} & \multicolumn{2}{|c|}{$\begin{array}{l}\text { Wspólautorstwo } \\
\text { międzynarodowe } \\
\text { (tys.) }\end{array}$} & \multicolumn{2}{|c|}{$\begin{array}{l}\text { Wspólautorstwo } \\
\text { międzynarodowe } \\
\text { w \% }\end{array}$} & \multicolumn{2}{|c|}{$\begin{array}{l}\text { CNCI** dla } \\
\text { wspólautorstwa } \\
\text { międzynarodo- } \\
\text { wego }\end{array}$} \\
\hline & $\begin{array}{l}2005- \\
2009\end{array}$ & $\begin{array}{l}2010- \\
2014\end{array}$ & $\begin{array}{l}2005- \\
2009\end{array}$ & $\begin{array}{l}2010- \\
2014\end{array}$ & $\begin{array}{l}2005- \\
2009\end{array}$ & $\begin{array}{l}2010- \\
2014\end{array}$ & $\begin{array}{l}2005- \\
2009\end{array}$ & $\begin{array}{l}2010- \\
2014\end{array}$ \\
\hline Globalnie & 6984,45 & 8910,05 & 1079,30 & 1638,10 & $15,45 \%$ & $18,38 \%$ & - & - \\
\hline UE-28 & 2398,31 & 2984,80 & 721,10 & 1042,59 & $30,07 \%$ & $34,93 \%$ & 1,37 & 1,41 \\
\hline Polska & 98,64 & 135,66 & 30,50 & 40,01 & $30,66 \%$ & $29,50 \%$ & 1,12 & 1,37 \\
\hline Węgry & 31,23 & 36,98 & 14,04 & 18,55 & $44,96 \%$ & $50,18 \%$ & 1,24 & 1,43 \\
\hline Słowacja & 15,80 & 24,13 & 6,79 & 9,54 & $43,01 \%$ & $39,93 \%$ & 0,96 & 1,21 \\
\hline
\end{tabular}

* W analizie uwzględniono: artykuły, rozdziały z książek i książki, artykuły przeglądowe i materiały konferencyjne.

** CNCI - Category Normalized Citation Impact.

Źródło: obliczenia własne na podstawie danych bazy Web of Science ${ }^{\mathrm{TM}}$ Core Collation [InCites Dataset, 2016].

Spośród wszystkich prac z polską afiliacją zindeksowanych w bazie WoS w latach 2005-2009 niecałe 31\% powstało przy udziale międzynarodowego współautora. Na tym tle zdecydowanie lepiej prezentują się publikacje $\mathrm{z}$ afiliacją słowacką (43,01\%) oraz węgierską (prawie 45\%). Uzyskane przez analizowane kraje wskaźniki w tym zakresie są dwu- (w porównaniu z polskimi tekstami), a nawet trzykrotnie wyższe (w przypadku słowackich i węgierskich prac) od danych dotyczących publikacji z międzynarodowym współautorstwem w ujęciu globalnym $-15,45 \%$ (tabela 4 ). 
W kolejnym analizowanym okresie (2010-2014) liczba prac uwzględnionych w badaniu współautorstwa międzynarodowego w poszczególnych krajach wykazała, że najwyższy poziom ponadnarodowej współpracy uzyskały publikacje $\mathrm{z}$ afiliacją węgierską (wzrost o 5\%). Okazuje się, że co drugi tekst $\mathrm{z}$ afiliacją tego kraju $(50,18 \%)$ powstał przy udziale współautora zagranicznego. W przypadku publikacji z polską afiliacją (spadek o ok. 1\%) dotyczy to co trzeciej pracy $(29,50 \%)$ z bazy WoS. Nieco częściej, choć w mniejszym stopniu niż w latach 2005-2009, współautorstwo międzynarodowe występuje w przypadku tekstów z afiliacją słowacką (prawie 40\%) (tabela 4).

Warto także rozważyć, czy współpraca międzynarodowa może wpływać na podniesienie rangi prowadzonych badań i publikowanych artykułów (ich cytowalności). W celu zweryfikowania tej zależności porównano wskaźnik Category Normalized Citation Impact i liczebności zbioru dla wszystkich prac pochodzących z badanych krajów oraz dla publikacji z danego państwa, które powstały w ramach współpracy międzynarodowej. Okazało się, że współpraca międzynarodowa była korzystna dla wszystkich analizowanych państw i znacząco podniosła cytowalność pochodzących z nich publikacji według wskaźnika CNCI. Odnosi się to zarówno do pierwszego (2005-2009), jak i drugiego (2010-2014) analizowanego okresu (tabela 4). Pozytywny wpływ współpracy międzynarodowej na liczbę powoływań publikacji powstałej w wyniku ponadnarodowej współpracy odnosi się przede wszystkim do prac z afiliacją polską i słowacką. Okazuje się, że poziom oddziaływania takich publikacji jest znacznie wyższy niż prac bez współautora zagranicznego (tabele 3 i 4).

\section{Dyskusja i uwagi końcowe}

Celem niniejszego artykułu była próba odpowiedzi na pytanie, czy wdrażane w pierwszej dekadzie XXI wieku reformy służące rozwojowi nauki i badań analizowanych państw, a przez to wzmocnieniu międzynarodowej pozycji ich nauki poprzez jej intensywne umiędzynarodowienie, przyniosły oczekiwane rezultaty. Aby to sprawdzić, dokonano porównania: (1) aktywności publikacyjnej pracowników sektora nauki i badań z Polski, Słowacji i Węgier w latach 20052009 (okres tworzenia odpowiednich ram prawnych i wdrażania reform) oraz 2010-2014 (okres realizacji przyjętych wcześniej strategii rozwoju wspomnianego sektora); (2) skali umiędzynarodowienia dorobku naukowego przedstawicieli tych państw (współautorstwo międzynarodowe); oraz (3) poziomu obecności naukowców z wymienionych krajów w europejskim (UE) i światowym obiegu nauki (cytowalność).

Porównując produktywność naukową w dwóch okresach (2005-2009 i 2010 2014), można dostrzec, że w tym drugim mamy do czynienia z niewielką tendencją wzrostową udziału prac z afiliacją polską i słowacką w światowych zasobach bazy WoS ${ }^{c c}$. Okazuje się, że od 2010 do 2014 roku spod pióra polskich i słowackich autorów wyszło więcej tekstów indeksowanych we wspomnianej bazie niż w latach 
2005-2009 - udział tych prac w zasobach światowych zwiększył się kolejno o 8\% i 17\%. Jeśli idzie o Węgrów, to niestety w drugim analizowanym okresie pojawia się tendencja spadkowa ich aktywności publikacyjnej. Udział prac z afiliacją węgierską w ogólnej liczbie rekordów wspomnianej bazy zmniejszył się w porównaniu $z$ danymi z lat 2005-2009 o ok. $10 \%{ }^{10}$.

Ten stan rzeczy nie pozostawał bez wpływu na inny wskaźnik opisujący aktywność publikacyjną autorów z omawianych trzech państw Europy Środkowo-Wschodniej. Chodzi o liczbę prac zindeksowanych w bazie WoS ${ }^{c c}$ przypadających na jednego pracownika sektora nauki i badań. Należy zaznaczyć, że w pierwszym analizowanym okresie (2005-2009) statystycznie średnio na jednego pracownika wspomnianego sektora z Polski i Węgier przypadała mniej niż jedna praca (w Polsce - 0,83, na Węgrzech - 0,91). W przypadku Słowacji wskaźnik ten wyniósł - 1,06 ${ }^{11}$. W kolejnych latach (2010-2014) wskaźniki te uległy poprawie, choć w różnym stopniu. Największy progres nastąpił na Słowacji, bo prawie o $42 \%$ w stosunku do okresu 2005-2009, i był najwyższy wśród wszystkich analizowanych państw. W Polsce był nieco niższy (28\%). W omawianym czasie wskaźnik ten wyniósł dla polskich autorów 1,06. Najmniejszy wzrost zanotowano na Węgrzech (5\%). Liczba publikacji przypadających na jednego pracownika sektora nauki i badań w latach 2010-2014 w tym kraju wyniosła 0,95.

Przedstawione powyżej dane pozwalają przyjąć tezę, że spośród przedstawicieli sektora nauki i badań analizowanych państw jedynie autorzy ze Słowacji (w obu uwzględnionych w badaniu okresach) oraz pracownicy naukowi z Polski

10 Inną ciekawą tendencją, którą można dostrzec dzięki przeprowadzonej analizie bibliometrycznej, jest to, że w omawianym okresie zmienił się w bazie WoS ${ }^{\mathrm{cc}}$ stosunek udziału publikacji z badanych państw w zakresie poszczególnych obszarów nauk. WoS ${ }^{\mathrm{cc}}$ jest bazą specyficzną, ponieważ zdecydowana większość zawartych w niej prac poświęconych jest naukom przyrodniczo-technicznym (science technology). Jedynie niewielki odsetek stanowią publikacje z zakresu nauk społecznych, humanistycznych oraz sztuki (social science and arts humanities). Ten najbardziej znany światowy indeks cytowań jest więc zdominowany przez dziedziny nauk ścisłych, które stanowią blisko $90 \%$ publikacji. Nauki społeczne i humanistyczne to ok. 10\% prac [za: InCitesTM Journal Citation Report, 2016]. Wspomniana analiza ujawniła zwiększenie procentowego udziału tekstów z obszaru nauk społecznych i humanistycznych w światowych zasobach tej bazy. Tendencja ta dotyczy każdego z badanych państw. W stopniu największym wzrost ten nastąpił wśród publikacji z afiliacją węgierską - aż o 123\%. Oznacza to, że co szósta węgierska praca zindeksowana w latach 2010-2014 w bazie WoS ${ }^{\mathrm{cc}}$ reprezentowała obszar nauk społecznych i humanistycznych. W przypadku Słowacji co dziewiąta, a Polski co szesnasta.

11 Prowadzone do tej pory analizy bibliometryczne wskazują, że przedstawiciele nauki państw byłego bloku wschodniego charakteryzują się znacznie niższym poziomem obecności w światowym obiegu nauki w porównaniu z państwami zachodnimi [Csajbók i in., 2007; Kozak i in., 2015; Kwiek, 2015a, 2016; Mali, 2011; Wróblewski, 2013 etc.]. Bez wątpienia ogromny wpływ na taki stan rzeczy miała przeszłość krajów Europy Wschodniej, które do roku 1989 funkcjonowały jako państwa socjalistyczne, z pełnymi w tym zakresie konsekwencjami dla ich nauki, m.in. objawiającym się znacznym izolowaniem ich pracowników naukowych od nauki zachodniej [Teodorescu, Andrei, 2011: 713]. Również przechodzenie przez badane państwa trudnego okresu transformacji systemowej w pierwszych latach po upadku żelaznej kurtyny nie pozostało bez wpływu na realizowaną przez te kraje politykę naukową i przekładało się także na niższą w porównaniu z państwami zachodnimi produktywność naukową i jej umiędzynarodowienie [Balazs i in., 1995; Mali, 2011]. 
(ale to dopiero w latach 2010-2014) byli w stanie osiągnąć statystyczny wskaźnik średnio jednej pracy z Impact Factorem przypadającej na jednego badacza ${ }^{12}$. Okazuje się, że pracownicy tego sektora z Polski i Węgier w latach 2005-2009, a w przypadku węgierskich naukowców także w drugim analizowanym okresie, nie potrafili przez pięć lat opublikować średnio choćby jednego tekstu indeksowanego $\mathrm{w}$ bazie $\mathrm{WoS}^{\mathrm{cc}}$ przypadającego na jednego statystycznie pełnozatrudnionego pracownika naukowego omawianego sektora nauki i badańn ${ }^{13}$.

Analizując zmiany i zaistniałe różnice w zakresie aktywności publikacyjnej przedstawicieli świata nauki i badań z Polski, Słowacji i Węgier w latach 20052009 i 2010 - 2014, warto podjąć próbę wskazania na niektóre predyktory, mogące mieć wpływ na badaną produktywność (w kontekście ilościowym i jakościowym). Oczywiście nie sposób w tym artykule omówić ich wszystkich, ale warto przytoczyć przynajmniej te, które najczęściej są analizowane w literaturze przedmiotu [zob.: Fox, 1992; Kwiek, 2015b, 2015c, 2016; Kwiek, Antonowicz, 2015; Pianta, Archibugi, 1991; Rozmus, 2012; Wolszczak-Derlacz i in., 2010; Mali, 2011].

Jednym z najważniejszych czynników determinującym aktywność badawczą, a tym samym i publikacyjną, jest wzrost nakładów finansowych na naukę i badania [Kwiek, 2015b, 2015c; Wolszczak-Derlacz i in., 2010]. W analizowanych krajach w omawianych okresach dostrzegamy stały wzrost tych nakładów, przy czym jego dynamika najwyższa była na Słowacji, z 0,49\% PKB w roku 2005 do 0,88\% PKB w roku 2014 (wzrost o 80\%) i w Polsce, analogicznie - 0,56\% i 0,94\% PKB (wzrost o 68\%). W przypadku Węgier wzrost ten nie był już tak znaczny. W roku 2005 nakłady na naukę i badania wyniosły $0,92 \%$ PKB, by w roku 2014 osiągnąć wartość 1,36\% PKB (wzrost o 48\%) [Eurostat, 2016a].

Jeszcze ciekawiej w tej kwestii prezentują się nakłady na badania i rozwój w sektorze szkolnictwa wyższego, którego przedstawiciele w dużej mierze odpowiadają

12 Być może wpływ na taki stan rzeczy (większą produktywność naukową) mają obowiązujące na Słowacji przepisy określające m.in. minimalne kryteria ilościowe, które powinien spełniać kandydat w momencie występowania o wszczęcie procesu nadania stopnia doktora habilitowanego. Położono w nich m.in. nacisk na wstępną ocenę profilu kandydata pod względem naukowym za pomocą przyjętych orientacyjnych parametrów ilościowych, jednocześnie zobowiązując przewodniczących komisji do spraw obron habilitacyjnych do informowania kandydatów niespełniających tych wymagań o konieczności ich uzupełnienia. Habilitant aplikujący o wszczęcie postępowania habilitacyjnego powinien posiadać m.in. określoną minimalną liczbę zagranicznych cytowań, w tym cytowanie prac na podstawie Science Citation Index - i określoną minimalną liczbę zagranicznych publikacji w czasopismach $\mathrm{z}$ odpowiednim IF. Taki wymóg stanowi wstępną formalną kontrolę tego, czy prace danego kandydata są w obiegu międzynarodowym [za: Rzepka, 2010: 110-112]. Można przypuszczać, że na taki stan rzeczy ma również wpływ proporcja liczby pracowników akademickich w grupie pracowników badawczych zatrudnionych w sektorze B $+\mathrm{R}$ w poszczególnych krajach. Np. w Polsce nauczyciele akademiccy ze stopniem doktora i wyższym stanowili w 2005 roku 40,78\% ogółu pracowników w tym sektorze, na Węgrzech - 25,4\%, a na Słowacji - 63,2\%. W roku 2014 analogicznie: w Polsce $-41,14 \%$, na Węgrzech - 27,8\%, a na Słowacji - 83,35\% [Eurostat, 2016c].

13 Dla porównania: w tym samym okresie (2005-2009) na jednego pełnozatrudnionego pracownika sektora nauki i badań (włącznie z nauczycielami akademickimi) w Holandii przypadało średnio 1,95 pracy, by w latach 2010-2014 osiągnąć wskaźnik 2 publikacji indeksowanych w bazie WoS ${ }^{\mathrm{cc}}$ [Middleton, Slikkerveer, 2011, 2012; OECD.Stat, 2016; Thomson Reuters, 2016c]. 
za wspomnianą produktywność naukową. I w tym przypadku największy wzrost środków finansowych nastąpił na Słowacji, z 0,1\% PKB w roku 2005 do 0,3\% PKB w roku 2014. W Polsce także zwiększały się te nakłady, przy czym nie w takiej skali jak na Słowacji. W roku 2005 wydatki na badania i rozwój w sektorze polskiego szkolnictwa wyższego wyniosły $0,18 \%$ PKB, a w roku 2014 było to $0,27 \%$ PKB. Z odmienną sytuacją mamy do czynienia na Węgrzech. W roku 2005 nakłady finansowe na badania i rozwój wynosiły $0,23 \%$ PKB, a w 2014 już tylko $0,18 \%$. Niestety od roku 2010 mamy w tym zakresie do czynienia ze stałym spadkiem nakładów finansowych w sektorze węgierskiego szkolnictwa wyższego. W stosunku do roku 2005 wydatki te w roku 2014 były niższe o 28\% [Eurostat, 2016b].

W kontekście przytoczonych danych dostrzegalna jest korelacja pomiędzy produktywnością naukową przedstawicieli Polski, Węgier i Słowacji a nakładami finansowymi na naukę i badania w tych krajach. Wskaźniki produktywności w latach 2010-2014 w stosunku do danych z lat 2005-2009 poprawiły Polska i Słowacja, natomiast Węgry zanotowały regres w tym zakresie.

Jak wspomniano, liczbę cytowań publikacji z afiliacją danego państwa można potraktować jako przybliżoną miarę uznania i ważności (w sensie pożyteczności) pracy naukowej przedstawicieli danego kraju, a tym samym określić poziom obecności ich uczonych $\mathrm{w}$ europejskim i światowym obiegu nauki. $Z$ pewnością wzrost liczby cytowanych prac, a szczególnie cytowań przypadających na publikację, świadczyć może o rosnącej randze badań prowadzonych przez naukowców danego kraju. Przeprowadzone analizy pozwalają zauważyć, że w latach 2010-2014 wszystkie omawiane kraje, których prace zostały zindeksowane w bazie WoS ${ }^{\mathrm{CC}}$, poprawiły wskaźniki cytowań CNCI (Category Normalized Citation Impact) w stosunku do lat 2005-2009, uzyskując w przypadku publikacji ze słowacką $(1,1)$ i węgierską $(1,04)$ afiliacją wyższe średnie wartości tego wskaźnika od globalnego $(0,98)$ oraz nieco niższą od regionalnego dla 28 obecnych członków UE $(1,13)$. Mimo że w drugim analizowanym okresie (2010-2014) wskaźnik CNCI wzrósł także dla polskich prac, to nadal był niższy od $1(0,92)$, a więc indeksowane w bazie teksty polskich naukowców miały słabszą moc oddziaływania niż prace węgierskie, a w szczególności słowackie.

Dotychczasowe badania potwierdzają także, że prócz nakładów finansowych również umiędzynarodowienie nauki i badań znacznie wpływa na poziom i jakość produktywności naukowej [Kwiek, 2015a, 2016; Wolszczak-Derlacz i in., 2010]. $\mathrm{W}$ przypadku badanych państw stopień umiędzynarodowienia ich nauki w analizowanych dwóch okresach, jako udział w ogólnej liczbie publikacji, które zostały stworzone wspólnie z reprezentantami instytucji naukowych z innych krajów, jest zróżnicowany, przy czym jest dwu- lub trzykrotnie wyższy od wskaźnika globalnego i nieco wyższy od regionalnego (UE-28). Wyjątek stanowi tu przypadek polskich prac powstałych z współautorem międzynarodowym w latach 20102014 - ich odsetek był niewiele niższy od wskaźnika regionalnego (dla UE-28) ${ }^{14}$.

14 Interesujące jest również to, że po upadku żelaznej kurtyny współpraca pomiędzy badaczami z krajów Europy Wschodniej nie zmniejszyła się: w większości tych państw nawet nieco wzrosła. Dynamicznie w porównaniu z wcześniejszym okresem zwiększyła się z kolei liczba wspólnych pub- 
W analizowanych okresach prawie co drugi węgierski i słowacki tekst (szczególnie zaś z afiliacją węgierską) powstał przy udziale współautora zagranicznego (zob. tabela 4). Najrzadziej współautorstwo międzynarodowe występowało $\mathrm{w}$ odniesieniu do tekstów z afiliacją polską, zarówno w pierwszym, jak i drugim okresie uwzględnionym w badaniu. W przypadku Polski co trzecia praca miała współautorstwo międzynarodowe. Taki stan rzeczy nie pozostawał bez wpływu na znormalizowany wskaźnik CNCI publikacji z afiliacją badanych państw zindeksowanych w bazie WoS. Okazało się, że współpraca międzynarodowa była korzystna dla wszystkich analizowanych państw, znacząco podniosła w latach 2010-2014 znormalizowane wskaźniki cytowalności (CNCI) tych prac, co oznacza, że miały wyższy od oczekiwanego poziom oddziaływania. Ponadto poziom oddziaływania takich publikacji jest znacznie wyższy niż tekstów bez współautora zagranicznego. Pozytywny wpływ współpracy międzynarodowej na wskaźnik CNCI publikacji powstałych w wyniku ponadnarodowej współpracy w latach 2010-2014 w stosunku do danych z lat 2005-2009 odnosi się przede wszystkim do prac $\mathrm{z}$ afiliacją słowacką.

Z przytoczonych danych płynie wyraźny przekaz. Dla poprawienia wskaźników naukowej efektywności publikacyjnej badaczy z analizowanych państw, a tym samym zwiększenia ich wpływu oddziaływania na naukę, pożądane jest pogłębianie międzynarodowej współpracy badawczej ${ }^{15}$.

Uzyskane wyniki z badań pozwalają przyjąć tezę, że wdrażane przez Polskę i Słowację reformy oraz rozwiązania strukturalne mające efektywnie wspierać konkurencyjność badawczą i naukową tych państw, także w wymiarze międzynarodowym, przynoszą powoli oczekiwane rezultaty. Uzyskane wyniki wskazują na zwiększenie udziału badanych państw w światowej nauce, a przedstawiciele tych krajów w coraz większym stopniu są obecni w światowym obiegu nauki. W przypadku Węgier sytuacja nie jest już tak jednoznaczna. Z jednej strony cytowalność prac $\mathrm{z}$ afiliacją węgierską wzrosła, $\mathrm{z}$ drugiej zaś zmalała produktywność naukowa przedstawicieli tego kraju, co skutkuje zmniejszeniem udziału ich publikacji ogółem w światowych zasobach bazy $\mathrm{WoS}^{16}$. Oczywiście w przypad-

likacji z autorami zachodnimi [Teodorescu, Andrei, 2011]. Jak pokazują badania, absolutnie numerem jeden wśród zachodnich współautorów są naukowcy z USA i Niemiec. Obecnie współpraca międzynarodowa $\mathrm{z}$ tymi państwami jest częstsza niż z innymi krajami byłego bloku wschodniego [Kozak i in., 2015].

15 Jak podkreśla M. Kwiek, obecnie (również w krajach naszego regionu) coraz mocniej w nauce zaczyna się liczyć nie sama publikacja, ale miejsce jej wydania; następnie już nie tylko samo jej wydanie, lecz międzynarodowy oddźwięk w nauce, czyli kumulujący się przez lata poziom cytowalności [Kwiek, 2015b: 62].

16 Jak zauważa Balintem Magyar (socjolog, nauczyciel akademicki, były minister oświaty w rządzie węgierskim w latach 1996-1998 i 2002-2006), na taki stan rzeczy wpłynęła zmiana prawa dotycząca pozyskiwania środków finansowych na badania przez instytucje akademickie po objęciu władzy na Węgrzech w 2010 roku przez partię Fidesz. Wcześniej uczelnie rywalizowały między sobą o granty badawcze. Po wprowadzonych zmianach ministerstwo przydziela je według uznania. Jak podkreśla Magyar, decydują o tym relacje między pracownikami ministerstwa a rektorami uniwersytetów. Ponadto w pierwszych latach rządów Viktora Orbána zmniejszono nakłady na uczelnie o ok. jedną trzecią [za: Kokot, 2017]. 
ku Polski i Słowacji kierunek przyjętych zmian wydaje się słuszny, co wcale nie oznacza, że „zdanie domowe” w tej kwestii jest już odrobione.

Ze względu na objętość artykułu autorzy nie mogli wyjść poza najbardziej podstawowe analizy i wskaźniki dotyczące produktywności naukowej badaczy $\mathrm{z}$ analizowanych państw. W konsekwencji nie podjęto bardziej szczegółowego omówienia i przeanalizowania wielu predyktorów determinujących aktywność publikacyjną. Warto tu wspomnieć choćby o kwestii istotnego wpływu na publikowalność nie tylko poziomu finansowania nauki i badań, lecz także jego źródła. Jak bowiem pokazują badania, im większa proporcja środków pochodzących ze źródeł publicznych, tym niższa efektywność badawcza, a tym samym i niższa produktywność naukowa [por. Wolszczak-Derlacz i in., 2010]. Z badań Kwieka [2015b] wynika z kolei, że warto byłoby także przeanalizować w kontekście produktywności naukowej przedstawicieli nauki badanych krajów dystrybucję czasu przeznaczonego przez pracowników akademickich na aktywność związaną z badaniami i z kształceniem oraz ich ukierunkowanie na konkretne role akademickie (kształcenie lub badania). Okazuje się bowiem, że przewaga czasu poświęconego na kształcenie powoduje zmniejszenie produktywności, a m.in. z takim dominującym wzorcem pracy mamy do czynienia w naszej części Europy [Kwiek, 2015b: 66].

Bez wątpienia głębszej i dodatkowej analizy wymagają kwestie poziomu i intensywności współpracy międzynarodowej w badaniach naukowych, w tym ich ukierunkowania na badania międzynarodowe (międzynarodowe granty badawcze), które przecież znacząco wpływają na produktywność naukową. Należałoby również skorelować wdrażane $\mathrm{w}$ ramach reform i strategii w badanych krajach zmiany wymogów awansowych, wymogów grantowych czy reguł parametryzacji z produktywnością naukową.

Niewątpliwym ograniczeniem przeprowadzonych analiz jest również to, że oparte zostały one tylko na pięciu bazach danych ISI pakietu Web of Science ${ }^{\mathrm{TM}}$ Core Collection. Dodajmy, iż bazy ISI, mimo że najstarsze i - jak się wydaje - najczęściej stosowane w praktyce analiz bibliograficznych [Marszakowa-Szajkiewicz, 1996: 15 i nn.; 2008: 33 i nn.; Nowak, 2006: 40 i nn.], nie są aktualnie jedynymi międzynarodowymi bazami dostępnymi do badań bibliometrycznych. Coraz większe znaczenie zyskują choćby baza Scopus prowadzona przez wydawnictwo Elsevier [Archambault i in., 2009; Ball, Tunger, 2006] czy Google Scholar [BarIlan, 2008; Freeman i in., 2009; Jacso, 2005; Kousha, Thelwall, 2008; Kulkarni i in., 2009; Meho, Yang, 2007]. Przy czym niewątpliwą zaletą wspomnianych baz ISI jest dostępność oprogramowania umożliwiającego prowadzenie wielu samodzielnych analiz [Grygiel i in., 2010: 79-81].

Ponadto wszystkie dostępne międzynarodowe bazy danych - ze względu na sposób ich konstruowania - mają charakter anglocentryczny [Van Leeuwen i in., 2001]. W konsekwencji niezbyt nadają się one do kompleksowych (uwzględniających również wymiar narodowy) analiz bibliograficznych autorów spoza kręgu anglosaskiego - choć, jak się wydaje, umożliwiają ocenę obecności uczonych w międzynarodowej wymianie myśli naukowej. 


\section{Bibliografia}

Archambault É., Campbell D., Gingras Y., Larivière V. (2009), Comparing Bibliometric Statistics Obtained from the Web of Science and Scopus, „Journal of the American Society for Information Science and Technology”, 60(7), 1320-1326, https://doi.org/10.1002/ asi.21062.

Balazs K., Faulkner W., Schimank U. (1995), Transformation of the Research Systems of PostCommunist Central and Eastern Europe: An Introduction, „Social Studies of Science”, 25(4), 613-632.

Ball R., Tunger D. (2006), Science Indicators revisited - Science Citation Index versus SCOPUS: A Bibliometric Comparison of Both Citation Databases, „Information Services and Use", 4(24), 239-301.

Bar-Ilan J. (2008), Which h-index? A Comparison of WoS, Scopus and Google Scholar, „Scientometrics", 74(2), 257-271, https://doi.org/10.1007/s11192-008-0216-y.

Beblavý M. (ed.) (2005), Competitiveness Strategy for the Slovak Republic until 2010: National Lisbon Strategy, Ministry of Finance of the Slovak Republic, Bratislava.

Csajbók E., Berhidi A., Vasas L., Schubert A. (2007), Hirsch-Index for Countries Based on Essential Science Indicators Data, „Scientometrics”, 73(1), 91-117. https://doi.org/10.1007/ s11192-007-1859-9.

De Bellis N. (2009), Bibliometrics and Citation Analysis: From the Science Citation Index to Cybermetrics, Md: Scarecrow Press, Lanham.

Drabek A. (2012), Wykorzystanie bibliometrii w polityce naukowej, „Biuletyn EBIB. Bibliometria w Bibliotekach”, 130(3), http://www.ebib.pl/images/stories/numery/130/130_drabek.pdf [dostęp: 18.05.2016].

Drabek A. (2013), Do użytku bibliometrycznego... Niebibliograficzne wykorzystanie baz bibliograficznych [w:] Bibliograficzne bazy danych i ich rola w rozwoju nauki (t. 24: 1-12), Poznań, 17-19 kwietnia 2013, Stowarzyszenie EBIB, Materiały konferencyjne, http:// open.ebib.pl/ojs/index.php/Mat_konf/article/view/26/15 [dostęp: 18.05.2016].

Eurostat (2016a), DataMarket.com, https://datamarket.com/data/set/1a4s/total-rd-expenditur $\mathrm{e} \#$ !ds=1a4s!qq8=g.2.h\&display=line [dostęp: 13.04.2016].

Eurostat(2016b),DataMarket.com,https://datamarket.com/data/set/1b0b/total-rd-expenditure-gerd-by-sectors-of-performance-and-type-of-rd-activity\#!ds=1b0b!sr3=1:sr4=2:6ft7=e. p.u:8anj=9\&display=line [dostęp: 13.04.2016].

Eurostat (2016c), Data.TrendEconomy, http://data.trendeconomy.com/dataviewer/eurostat/ rd_p/rd_p_persocc?geo=HU,PL,SK\&occup=RSE\&sectperf=HES,TOTAL\&unit=FTE [dostęp: 12.12.2016].

Fox M.F. (1992), Research, Teaching, and Publication Productivity: Mutuality versus Competition in Academia, ,Sociology of Education”, 65(4), 293, https://doi.org/10.2307/2112772.

Freeman M.K., Lauderdale S.A., Kendrach M.G., Woolley T.W. (2009), Google Scholar versus PubMed in Locating Primary Literature to Answer Drug-related Questions, „The Annals of Pharmacotherapy", 43(3), 478-484, https://doi.org/10.1345/aph.1L223.

Górniak J. (red.) (2015), Diagnoza szkolnictwa wyższego. Program rozwoju szkolnictwa wyższego do 2020 r., t. 3, Warszawa: Wydawnictwo SGGW. 
Grygiel P., Rębisz S., Humenny G. (2010), Analiza bibliometryczna jako narzędzie badania efektywności nauczycieli akademickich. Przyklad Uniwersytetu Rzeszowskiego [w:] B. Jałocha, G. Prawelska-Skrzypek (red.), Współczesne zmiany w szkolnictwie wyższym oraz $w$ modelach kariery akademickiej (s. 65-84), Wydawnictwo Uniwersytetu Jagiellońskiego, Kraków.

GUS (2006), Szkoty wyższe i ich finanse w 2005 r., Warszawa.

GUS (2007), Szkoty wyższe i ich finanse w 2006 r., Warszawa.

GUS (2008), Szkoly wyższe i ich finanse w 2007 r., Warszawa.

GUS (2009), Szkoty wyższe i ich finanse w 2008 r., Warszawa.

GUS (2010), Szkoly wyższe i ich finanse w 2009 r., Warszawa.

GUS (2011), Szkoty wyższe i ich finanse w 2010 r., Warszawa.

GUS (2012), Szkoty wyższe i ich finanse w 2011 r., Warszawa.

GUS (2013), Szkoty wyższe i ich finanse w 2012 r., Warszawa.

GUS (2014), Szkoły wyższe i ich finanse w 2013 r., Warszawa.

GUS (2015), Szkoty wyższe i ich finanse w 2014 r., Warszawa.

Higher Education Governance in Europe: Policies, Structures, Funding and Academic Staff (2008), Eurydice, Brussels.

Hungarian Central Statistical Office (2016), Tertiary education (1990/1991-2015-2016). Budapest, http://www.ksh.hu/stadat_annual_2_6 [dostęp:11.01.2017].

InCites Dataset (2016), https://incites.thomsonreuters.com/\#/analytics [dostęp: 14.11.2016].

InCitesTM Journal Citation Report (2016) https://jcr.incites.thomsonreuters.com/JCRJournalHomeAction.action [dostęp: 23.09.2016].

Investment in the Future: National Research and Development and Innovation Strategy 20132020 (2013), National Innovation Office, Ministry for National Economy, Hungary.

Jacso P. (2005), As We May Search: Comparison of Major Features of the Web of Science, Scopus, and Google Scholar Citation-Based and Citation-Enhanced Databases, „Current Science", 9(89).

Klincewicz K., Żemigała M., Mijal M. (2012), Bibliometria w zarządzaniu technologiami i badaniami naukowymi, Ministerstwo Nauki i Szkolnictwa Wyższego, Warszawa.

Knight J. (2012), Concepts, Rationales, and Interpretive Frameworks in the Internationalization of Higher Education [w:] D.K. Deardorff, H. de Wit, J.D. Heyl, T. Adams (eds.), The SAGE Handbook of International Higher Education (ss. 27-42), SAGE Publications, London.

Kokot M. (2017), Viktor Orbán naraził stosunki z Donaldem Trumpem, chcac wyświadczyć przystugę Władimirowi Putinowi, „Gazeta Wyborcza”,http://wyborcza. pl/7,75399,21596989,viktor-orban-narazil-stosunki-z-donaldem-trumpem-chcac-wyswiadczyc.html [dostęp: 5.04.2017].

Kousha K., Thelwall M. (2008), Sources of Google Scholar Citations Outside the Science Citation Index: A Comparison between Four Science Disciplines, ,Scientometrics”, 74(2), 273-294, https://doi.org/10.1007/s11192-008-0217-x.

Kozak M., Bornmann L., Leydesdorff L. (2015), How Have the Eastern European Countries of the Former Warsaw Pact Developed since 1990? A Bibliometric Study, „Scientometrics", 102(2), 1101-1117, https://doi.org/10.1007/s11192-014-1439-8.

Krysztofiak-Szopa J. (2006), Badania cytowań w Filozofii Nauki, http://julia-krysztofiak. blogspot.com/2006/10/citation-pattern-among-authors-of.html [dostęp: 26.05.2016]. 
Kulkarni A.V., Aziz B., Shams I., Busse J.W. (2009), Comparisons of Citations in Web of Science, Scopus, and Google Scholar for Articles Published in General Medical Journals, „JAMA”, 302(10), 1092-1096, https://doi.org/10.1001/jama.2009.1307.

Kwiek M. (2015a), Inequality in Academic Knowledge Production: The Role of Research Top Performers Across Europe [w:] E. Reale, E. Primeri (eds.), The Transformation of University Institutional and Organizational Boundaries (s. 203-230), SensePublishers, Rotterdam.

Kwiek M. (2015b), Młoda kadra: różnice międzypokoleniowe w pracy naukowej i produktywności badawczej. Czym Polska różni się od Europy Zachodniej?, „Nauka”, (4), 51-88.

Kwiek M. (2015c), Umiędzynarodowienie badań naukowych - polska kadra akademicka z perspektywy europejskiej, „Nauka i Szkolnictwo Wyższe”, 1(45), 39-74.

Kwiek M. (2015d), Uniwersytet $w$ dobie przemian. Instytucje i kadra akademicka $w$ warunkach rosnacej konkurencji, Wydawnictwo Naukowe PWN, Warszawa.

Kwiek M. (2016), The European Research Elite: A Cross-national Study of Highly Productive Academics in 11 Countries, „Higher Education”, 71(3), 379-397.

Kwiek M., Antonowicz D. (2015), The Changing Paths in Academic Careers in European Universities: Minor Steps and Major Milestones [w:] T. Fumasoli, G. Goastellec, B.M. Kehm (eds.), Academic Work and Careers in Europe: Trends, Challenges, Perspectives (s. 41-68), Springer International Publishing, Cham, https://doi.org/10.1007/978-3319-10720-2_3.

Lewicka M. (2009), Niebezpieczne poglady, „Forum Akademickie”, 99(1).

Leydesdorff L. (1998), Theories of Citation?, „Scientometrics”, 43(1), 5-25.

Mali F. (2011), Policy Issues of the International Productivity and Visibility of the Social Sciences in Central and Eastern European Countries, „Sociology and Space”, 48(3), 415-435.

Marszakowa-Szajkiewicz I. (1996), Bibliometryczna analiza wspótczesnej nauki, Wydawnictwo Uniwersytetu Śląskiego, Katowice.

Marszakowa-Szajkiewicz I. (2008), Badania ilościowe nauki - podejście bibliometryczne $i$ webometryczne, Uniwersytet im. Adama Mickiewicza, Poznań.

Meho L.I., Yang K. (2007), Impact of Data Sources on Citation Counts and Rankings of LIS Faculty: Web of Science versus Scopus and Google Scholar, „Journal of the American Society for Information Science and Technology”, 58(13), 2105-2125, https://doi. org/10.1002/asi.20677.

Middleton P., Slikkerveer L. (2011), Key Figures 2006-2010: Education, Culture and Science, Ministry of Education, Culture and Science, Zoetermeer.

Middleton P., Slikkerveer L. (2012), Education, Culture and Science in the Netherlands Key Figures 2007-2011, Ministerie van onderwijs, cultuur en wetenschap, Zoetermeer.

Nowak P. (2006), Bibliometria, webometria. Podstawy. Wybrane zastosowania, Wydawnictwo Naukowe UAM, Poznań.

Nygaard L.P. (2015), Publishing and Perishing: An Academic Literacies Framework for Investigating Research Productivity, „Studies in Higher Education”, 1-14.

OECD.Stat (2016), http://stats.oecd.org/Index.aspx?DataSetCode=PERS_OCCUP [dostęp: 23.09.2016].

Olechnicka A., Płoszaj A. (2009), Polskie publikacje z zakresu nauk społecznych i humanistycznych w bazie Web of Science, ,Edukacja Ustawiczna Dorosłych”, 1(64), 35-45. 
Pianta M., Archibugi D. (1991), Specialization and Size of Scientific Activities: A Bibliometric Analysis of Advanced Countries, „Scientometrics”, 22(3), 341-358.

Przyłuska J., Maczuga J. (2011), Wskaźniki bibliometryczne w ocenie aktywności publikacyjnej pracowników naukowych, „Forum Bibliotek Medycznych”, 4(1), 516-520.

Rozmus A. (2012), Wybrane mierniki potencjatu polskiej nauki-widziane przez pryzmat kariery naukowej [w:] S. Waltoś, A. Rozmus (red.), Kariera naukowa w Polsce. Warunki prawne, spoleczne i ekonomiczne (s. 207-231), Oficyna Wydawnicza a Wolters Kluwer business, Warszawa.

Rzepka G. (2010), Kariera akademicka w Republice Stowackiej [w:] B. Jałocha, G. Prawelska-Skrzypek (red.), Wspótczesne zmiany $w$ szkolnictwie wyższym oraz w modelach kariery akademickiej, Wydawnictwo Uniwersytetu Jagiellońskiego, Kraków.

Statistical Office of the Slovak Republic (2010), Statistical Yearbook of the Slovak Republic (2010), Bratislava.

Statistical Office of the Slovak Republic (2015), Slovak Republic in Figures 2015, Bratislava.

Strategia rozwoju kraju 2007-2015. Strategia rozwoju nauki w Polsce do 2015 roku (2008), Ministerstwo Nauki i Szkolnictwa Wyższego, Warszawa.

Teodorescu D., Andrei T. (2011), The Growth of International Collaboration in East European Scholarly Communities: A Bibliometric Analysis of Journal Articles Published Between 1989 and 2009, „Scientometrics”, 89(2), 711-722, https://doi.org/10.1007/s11192011-0466-y.

Thomson Reuters (2016a), InCites: Indicators Handbook, http://ipscience-help.thomsonreuters.com [dostęp: 12.12.2016].

Thomson Reuters (2016b), InCitesTM Journal Citation Reports, https://jcr.incites.thomsonreuters.com [dostęp: 10.11.2016].

Thomson Reuters (2016c), InCitesTM Essential Science IndicatorsSM, https://esi.incites. thomsonreuters.com/DocumentsAction.action [dostęp: 26.05.2016].

Van Leeuwen T., Moed H., Tijssen R., Visser M., Van Raan A. (2001), Language Biases in the Coverage of the Science Citation Index and Its Consequencesfor International Comparisons of National Research Performance, „Scientometrics”, 51(1), 335-346.

Wolszczak-Derlacz J., Parteka A., Kuczyński J. (2010), Produktywność naukowa wyższych szkót publicznych w Polsce. Bibliometryczna analiza porównawcza, Ernst \& Young, Warszawa.

Wróblewski A.K. (2005), Nauka w Polsce wedtug rankingów bibliometrycznych, „Nauka”, (2). Wróblewski A.K. (2013), Pozycja nauki polskiej w międzynarodowych rankingach, „Studia BAS”, 35(3), 89-106. 